\title{
Disiplinlerarası Alanda Rölyef Üzerine Açılımlar: “Atölye İşleri” Örneği
}

\section{The Relief within Interdisciplinary Field: A Study Through "StudioWork" Döndü Tülay Özkul}

Arş. Gör., Ankara Hacı Bayram Veli Üniversitesi Güzel Sanatlar Fakültesi Heykel Bölümü email: dtulay_durmus@hotmail.com (DORCID ID: https://orcid.org/0000-0003-2789-5396

Atıf (APA 6)/To cite this article

Özkul, D. T. (2019). Disiplinlerarası alanda rölyef üzerine açılımlar: Atölye işleri örneği. Atatürk Üniversitesi Güzel Sanatlar Enstitüsü Dergisi, 43, 182-192. doi: https://doi.org/10.32547/ataunigsed.595727

Makale Gönderim Tarihi/Received: 23/07/2019

Makale Kabul Tarihi/Accepted: 16/10/2019

Makale Yayın Tarihi/Published: 26/10/2019

Review Article/Derleme Makalesi

\section{$\ddot{\mathbf{O z}}$}

Rölyef, herhangi bir düzlem üzerinde yükseltilerek ya da alçaltılarak elde edilen bir heykel formudur. Günümüzde de mimariden heykeltıraşlığa olduğu kadar endüstriyel üretimde de kendine bir yer edindiği görülür. Zemin üzerine inşa edilen rölyef, gerek heykelin gerekse resmin sahip olduğu biçimsel ve mekânsal koordinatları kullandı ̆̆ı için zengin bir dile sahiptir. Ancak günümüzde rölyef sanatı, geçmişte olduğu gibi kullanılmaya devam etmesine karșın, günümüz sanatçıları teknik bakımdan olduğu kadar kavramsal çerçeve açısından da yeni/özgün uygulamalar ile rölyef sanatının gelişmesine katkı sağlarlar.

$\mathrm{Bu}$ araştırmanın temel amacı, geçmişten günümüze rölyef heykelin konumunu merkeze alarak, bu bağlamda üretim yapan sanatçıların uygulamaları ve yapılan bireysel üretimler üzerinden çăgdaş sanata katkılarını ortaya koymaktır.

\begin{abstract}
Relief is a form of sculpture obtained by raising or lowering on any plane. Today, it is seen that this form has gained a place in industrial production as well as in architecture and sculpture. The relief built on the ground has a rich language because it uses both the formal and spatial coordinates of both the sculpture and the painting. However, although the relief art continues to be used as it was in the past, today's artists contribute to the spread of relief art with new and original ways in terms of conceptual frame work as well as in technical terms.

The aim of this research is to reveal the contribution of artists working in this field in to contemporary art with a focus on relief sculpture in a historical perspective and its effect on its present meanings.
\end{abstract}

Keywords: Relief, Sculpture, Painting, Ground, Platform

Anahtar Kelimeler: Rölyef, Heykel, Resim, Zemin, Düzlem

\section{Giriş}

Bu araştırmaya konu olan rölyef sanatı geçmişte olduğu gibi günümüz sanatında da yerini muhafaza ederek, çağdaş heykel sanatının bir parçası olmaya devam etmektedir. Günümüzde rölyef geleneksel olarak varlığını devam ettirmesinin yanı sıra, çağdaş sanatta üretim yöntemlerini de etkilemektedir. Bu sebeple rölyef bir pratik olarak birçok disiplinin ortak paydasında yer alarak, günümüz sanatçıları tarafından gündemde tutulmaya ve irdelenmeye devam etmektedir.

Öncelikle rölyef, Türk Dil Kurumunun resmi web sitesinde "Kil, alçı, taş vb. işlenebilir gereçleri girintili çıkıntılı yüzeyler durumunda biçimlendirerek yapılan eser" (TDK, 2019) olarak tanımlanmaktadır. Atıl ise rölyefi şöyle özetler:

Rölyef heykel, bir düzleme bağlı olarak gelişen, bu düzlemin altında ya da üstünde, resim ve serbest heykel arasındaki derinlik alanında varlık gösteren yani iki boyut (düzlem) ve üç boyut (hacim) içerisinde tartışılan ancak abartılı, gelişmiş resim, az geliş̧miş heykel ya da bunların bir karışımı gibi görülmemesi gereken bir sanat formudur (At1l, 2015, s. 2).

Rona ise rölyefi "Bir düzlem üstüne tasarlanıp gerçekleștirilen heykelcilik ürünü. Kabartma üç boyutlu heykele özgü niteliklerin yanı sıra perspektif gibi iki boyutlu resimsel öğelerden de yararlanır” șeklinde tanımlamaktadır (Rona, 2008, s. 680).

Rölyef köken olarak Fransızca relief' e dayanırken, relief ise İtalyanca aynı anlama gelen relievo kelimesinden devşirilmiştir. Relievo sözcüğü ise Latince yukarı kaldırmak, yükseltmek anlamına gelen relevare sözcüğünden türemiştir (Rölyef, 2019). Bu anlamda rölyef kelimesinin kendi de yüzey üzerinden yükselme ifadesini içinde barındırdığı görülmektedir.

Çağlar boyunca rölyef, mimaride vazgeçilmez bir unsur olarak yerini almış, farklı amaç ve niyetler etrafinda şekillenerek, heykelin ve resmin üstlenmiş olduğu anlatıcı rolü pekiștirmiştir. Hatta teknik bakımdan rölyefin resim ve heykelin eş değerliklerini içinde taşıması, yerine göre bu iki disiplinin önüne geçmesine neden olmuştur. 
Rölyef ile elde edilen ifade gücünün kaynağı hem resmin alt elemanlarından biri olan perspektifin illüzyonistlik bir katkı sağlaması hem de heykelin hacimsel davranışlarını aynı anda sergileyebilmesinden kaynaklanır. Tarih boyunca birçok uygarlık rölyefi bu disiplinler dâhilinde, ulaştırılması gereken mesajı organize ederek, gerek inançları temsil etmesi amacı ile gerek anıtsal ve dekoratif amaçlar için gerekse başka amaçlar ile kullandığı da görülmüştür.

\section{Yöntem}

$\mathrm{Bu}$ araştırmada betimsel yöntem kullanılmıştır. Konu kapsamında literatür taraması yapılmış olup, konu kapsamında üretim yapan sanatçıların eserleri araştırılıp, yorumlanmış ve değerlendirilmiştir. Sanatçı üretimlerinin yanı sıra bireysel uygulamalar üzerinden konu kendi koşulları ve tarihsel pratiği üzerinden incelenerek saptamalar yapılmış, günümüz sanatına katkılarını ortaya koymak amaçlanmıștır.

\section{Rölyef ve günümüz rölyef anlayışı}

\subsection{Geçmişten günümüze rölyef ve çeşitleri}

Tarih öncesi dönemlerden kalma toprak, kemik, taş ve fildiși gibi malzemelerden oyularak ya da yontularak elde edilen ana tanrıça heykelcikleri bu konuya örnek oluşturmaktadır. Bereketi temsil ettiğine inanılan kadın heykelcikleri Venüs olarak adlandırılmakta, Fransa'dan Sibirya'ya varlık göstermektedir (Absolon, 1949'dan aktaran Bostancı, 2014, s. 193). Pera Müzesi'nin açıklamasına göre, son yıllarda uzmanların iddiasına göre Venüs olarak adlandırılan bu heykelciklerin yapım tarihi, Roma ve Yunan mitolojisinde güzellik ve aşk tanrıçası olarak bahsi geçen Venüs'ten binlerce yıl öncesine tarihlendirildiği için Venüs olarak adlandırılmaları doğru bulunmamaktadır (aktaran Özkul, 2019, s. 31).

Bu sebeple tarih öncesi dönemlerden kalma bu bereket heykelcikleri bulundukları bölgenin adı ile tanımlanarak ardına 'Figürin' ibaresinin yerleştirilmesi daha doğru gözükmektedir. Hodder (2006)'ya göre, “İnsan bedenlerinin küçük röprodüksiyonları dünyadaki bütün arkeolojik kazı alanlarında sıkça görülür. Hayvan ve nesne heykelleriyle birlikte, bu küçük heykellere 'figürin' denir”' (aktaran Tekin, 2019, s. 57).

Bu heykelciklerin içinde yer alan Lassuel Kadın Figürin’i (Bkz. Görsel 1), rölyef tekniğinde yapılmıştır.

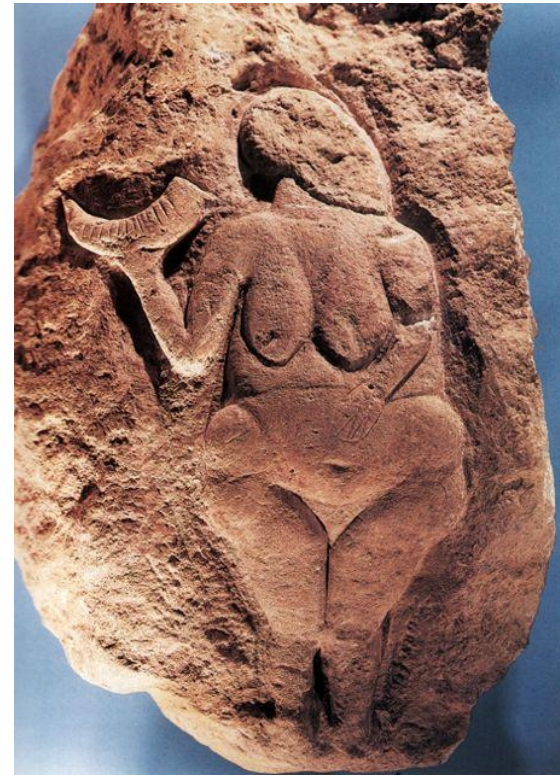

Görsel 1. Lassuel kadın figürin, M.Ö. 25000

Lassuel Kadını, o dönemin en kalıcı malzemeleri içinde yer alan kireç taşının üzerine oyulmuştur. Lassuel Kadınının da, bolluk ve bereketi simgelemesi açısından kalça ve göğüslerin abartılarak diğer bereket heykelcikleri ile benzer özellikler taşıdığı görülmektedir. Bağlı olduğu düzlemle figürün ilişkisi kesilmemiş yer yer derin oyuklar bırakılarak elde edilen derinlik vurgusu ile temsil kuvvetlendirilmiştir. Arka planla kurulan bağlantı değişkenliğinin verdiği özgün ifadenin yanı sıra zaman zaman yumuşak geçişler ile bütünleşme desteklenirken, yüzey üzerinde bırakılan keskin çizgisel formlar ile bütünlük sağlanmıştır.

Yüzey üzerinden çıkıntısı az olacak şekilde yükselerek inşa edilen/oluşturulan rölyefe alçak rölyef, çıkıntısı fazla olacak şekilde inşa edilen/oluşturulana yüksek rölyef adı verilirken yüzey üzerinden oyularak/çökertilerek yapılan rölyeflere çukur/oyma rölyef adı verilir (Yılmaz, 2006, s. 16). Ancak Atıl, rölyefi gruplara ayırırken kesme, alçak, orta ve yüksek olarak gruplandırır. Hatta bu gruplandırmanın bile yeterli gelmeyeceğini çünkü rölyef düzlemine 
inşa edilen her formun yüksekliğinin, birbirinden farklı özellikler göstererek belirli bir sınıflandırmanın içine giremeyeceği durumlar söz konusu olduğunu iddia eder (Atıl, 2015, s. 3). Öyle ki tek bir rölyefin içinde bütün rölyef grupların yer aldığı durumlar ile karşılaşırız. Örneğin Michelangelo tarafından yapılan mezar rölyefi, bu duruma örnek olarak verilebilir. Wölfflin, Michelangelo'nun geç döneminde Papa Julius mezarı için yapmış olduğu Musa heykelinin bağlı olduğu yüzeyden gerekenden fazla uzağa taşıdığını aktarır.

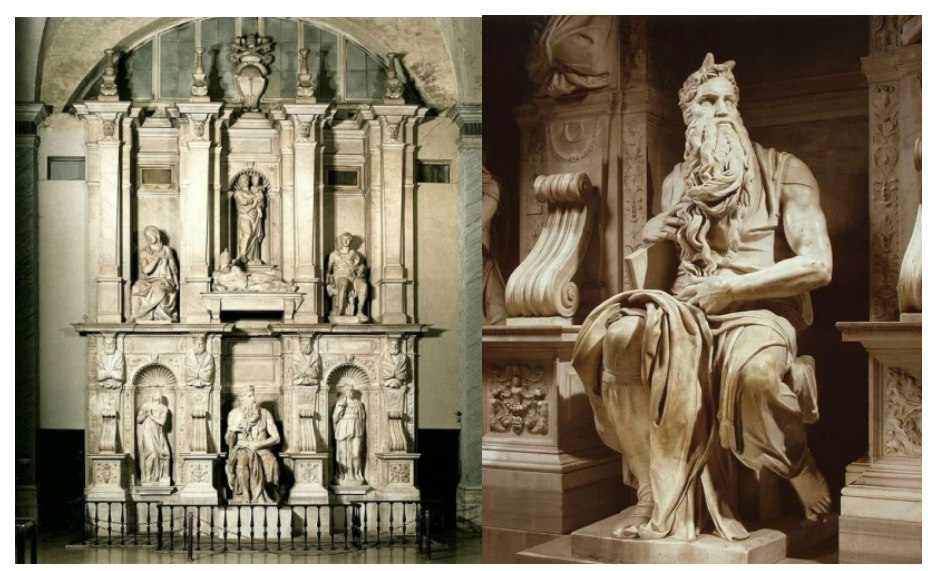

Görsel 2. Michelangelo, Musa,1513-1515

Musa'yı bağlantıda olduğu düzlemden o kadar uzağa taşımıştır ki artık bağlı olduğu rölyefin bir uzantısı değil, belli bir yüzeyde sonlanmayan bağımsız bir figür niteliği taşımaktadır (Wölfflin, 2015, s. 131).

Neredeyse bütün kabartma çeşitlerinin bulunduğu bu anıt mezarda rölyefin kendi kurallar çerçevesinden nasıl sıyrıldığına tanık oluruz. Öyle ki Wölfflin, geçmişte yapılan uygulamalara dayanarak figürün ya nişin içine ya da dışına sarkacak biçimde yapıldığını, klasik eserlerde ise heykeli duvar derinliğine hapseden bir anlayış söz konusu olduğunu söyler. Ancak Michelangelo'dan sonra bu bakış açısı var olan kurallar bütününde bir kırılmaya sebep olur (Wölfflin, 2015, s. 131).

Öte yandan Rogers ise, kesme rölyef hakkındaki düşüncelerini şöyle özetler:

Garip bir Mısır rölyef biçimi olan coelanaglypic ya da batık rölyef, en planimetrik olanıdır. Duvardan dışarı çıkmaz, nesnenin konturu etrafına oluk kesilerek oluşturulan sı̆̆ bir girinti içine oyulur. Mısır çizgisinin klasik katılığı ve netliği bu şekilde oluğu çevreleyen keskin dış kenarlarının ışı̆̆ yakalayışı ile güçlenir (Rogers, 1969, s.162).

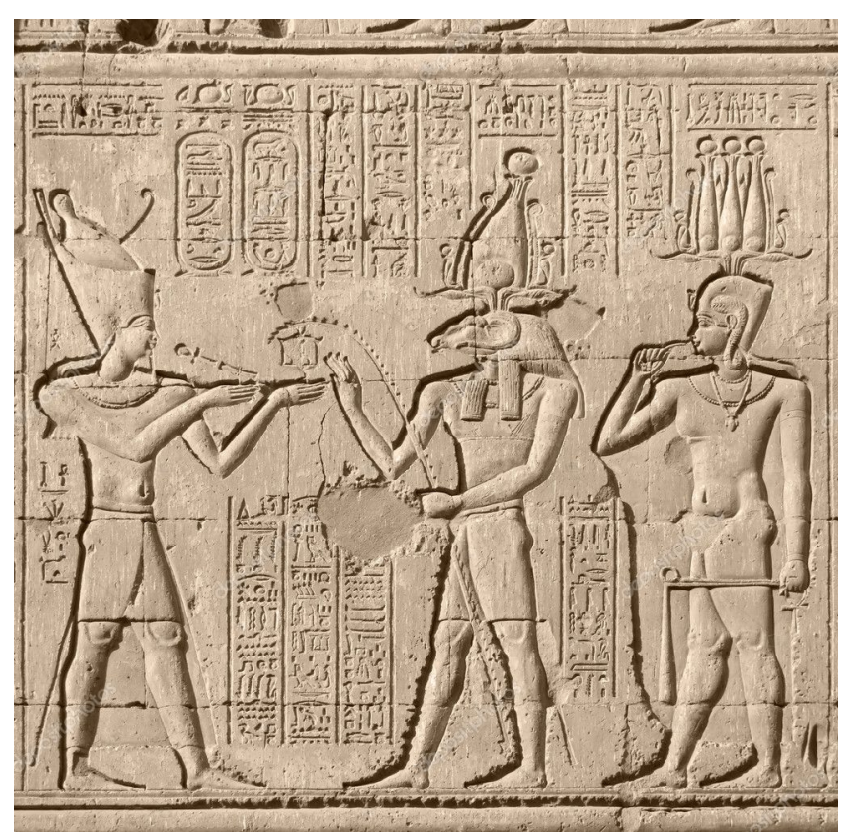

Görsel 3. Mısır'daki Chnum tapınağı'nda taş kabartma

Çoğu zaman derinlik kaygısı taşımayan bu rölyef tipinde, yüzey boyunca gerçekleşen anlatım biçiminde derinliği az olan görünüşler tercih edilirken mekân anlatımına yer verilmez (Turani, 2017, s. 61). Perihan Sadıkoğlu ise 
bunun sebebini, tasvirlerde yer alan figürleri tek boyutta yorumlama ve ifadelendirme gereksiniminden kaynaklandığ 1 şeklinde yorumlar (Sadıkoğlu, 2007, s. 71). Gombrich ise bu konuda heykelcinin sadece öz olanla ilgilendiği için görkemlilik ve yalınlığın bir arada olduğunu ifade eder... Gözlem ve tutarlılık öylesine iyi bir biçimde sentezlenmiştir ki onların gerçekçilikleri kadar uzak ve sonsuz oluşları da bizi derinden etkiler (Gombrich, 2015, s. 58). Rölyeflerin üzerinde yer alan hiyerogliflerin sahip olduğu anlatım gücü, resimsel anlatısı ile rölyefi desteklerken aynı zamanda biçimsel olarak onu yeniden şekillendirir.

Ayrıca mısır sanatında rölyefin anlatım gücü, mekân ve güneşin geliş açısı ile doru orantıdadır. Sadıkoğlu bu durumu şöyle açıklar:

Kabartmalar, 1şık ve gölge yoluyla tasvir teknikleri kullanılarak oyuntu ve çıkıntılarla şekillendirilmiştir. Çıkıntılı kabartmalarda, şekilleri çevreleyen yüzey 5 milimetre kadar gömük oyularak dışarıya doğru duruyor görüntüsü verilmiştir. Girintili kabartmalarda ise şekillerin dış çizgileri yüzeyin içine oyulmuştur. Dışa çıkık kabartmalar, daha çok yapıların içinde; güneşte daha belirgin, içeri girik kabartmalar ise yapıların dışında kullanılmıştır (Sadıkoğlu, 2007, s. 71).

Antik Mısırlılar rölyef tekniğini kendi üsluplarında etkileyici bir biçimde kullanmışlardır. Günümüzde yapılan rölyefler, antikitedekinin aksine malzeme açısından oldukça zengindir. Hatta günümüzde malzeme çeşitliliği sanatçının yaratıcılığını destekleyen bir yerde konumlanır. Bazen sanatçılar tarafından yapılan üretimler sadece malzeme çıkışlı olabilirken bazense yaratma sürecine giren sanatçı, yaratıcılı̆̆ malzeme arayışına girer. Sonuç olarak sanatçı yaratıcılığını, üslubunu, bilgilerini yorumlayıp, sentezleyip rölyefte somutlaştırır (Atalay, 2012).

\subsection{Günümüzde rölyef anlayışı/arayışı}

Günümüzde her disiplinde olduğu gibi tüketim nesneleri de rölyefin malzeme dağarcığına yerleşiktir. Özellikle tüketme eyleminden geriye kalan atık nesneler çağın sanatçıları tarafından kadraja alınmış, yaşamsal izleri barındırmaları açısından da kayda değer kabul edilmiştir (Yılmaz, 2015, s. 186). Waldman, (1992)'ye göre, bu bakımdan ilk referansımız Picasso tarafından 1908 yılında yapılan ilk kolajdır. Yapmış olduğu bir desenin üzerine Louvre Müzesine ait bir giriş biletini yapıştırarak resim düzleminin sorunlarına dikkat çekmiştir (aktaran Tıgın, 2014, s. 19). İlk olarak, kolaj tekniği ile yüzeye ilişmeye başlayan atık nesneler daha sonraları asamblaj tekniği ile üç boyutluluğu olanaklı kılınmış, söylemsel ve biçimsel olarak daha zengin bir dil oluşturduğu için birçok disiplinde dolaşıma girmiştir. Asamblaj tekniği ile yüzey üzerinde kütlesel ve hacimsel ifadeler rahatlıkla eritilerek, disiplinler arası bir alana işaret edilmiştir. Bu sebeple sanatçılar özellikle bu tekniği kullanarak rölyefin zenginleşmesine katkıda bulunmuşlardır.

\subsection{Günümüz rölyef anlayışında çağdaş uygulamalar}

20. yüzyıl sanatçılarından Loise Nevelson, birçok üretiminde olduğu gibi atığa dönüşen günlük kullanım nesnelerini, dikdörtgen bir düzlem üzerinde Gökyüzü Katedrali’nde bir araya getirir.

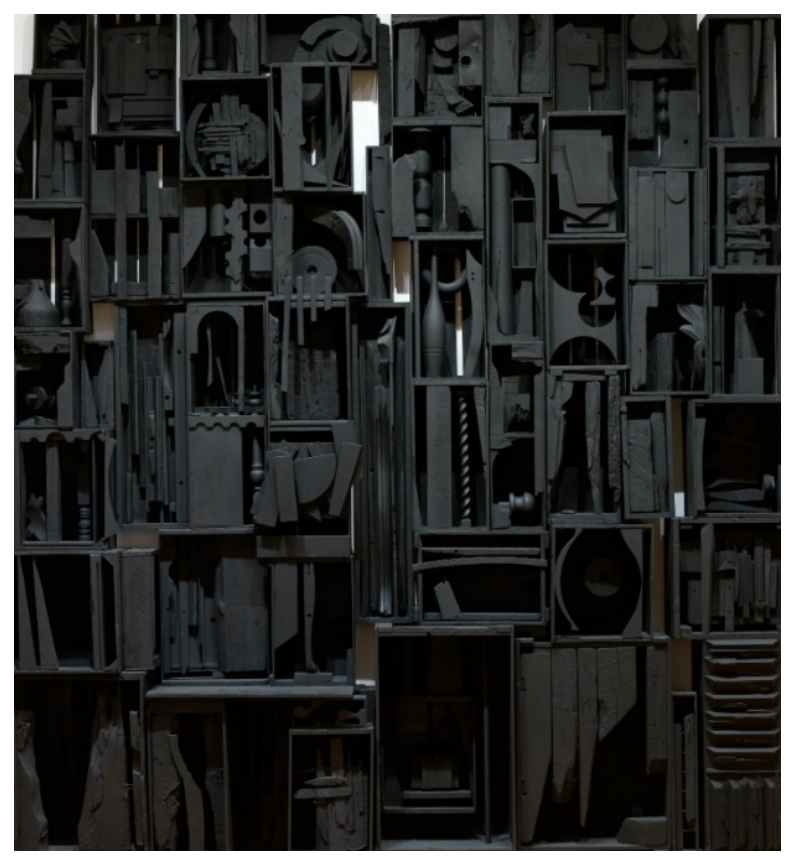

Görsel 4. Louise Nevelson, Gökyüzü Katedrali, 1958,343.9 × 305.4 × 45.7 cm, boyalı ahşap 
Sanatçı tarafından Katedralde yer alan boyanmış nesneler alçak ve yüksek ritimlerle yerleştirilerek, kendi içinde bir dinamik oluşturması sağlanmıştır. Bu ritimle oluşturulan parlak siyah yüzey üzerinde irili ufaklı gölgeler elde edilerek nesnelerin sahip olduğu arkeolojik geçmiş sessizleştirilmiştir (MoMA, 2019). Nevelson girinti ve çıkıntıları birbiri ile ilişkilendirirken koyu renk ve gölgelendirmeler ile desteklemiş, bu sayede terk edilen nesne fragmanları, sanatçı tarafindan ıssız bir manzaranın kendisine dönüştürülmüştür.

Nesne fragmanları ile rölyef formunun sınırlarını irdeleyen hatta zaman zaman zorlayan bir başka sanatçı ise Leonardo Drew'dir. Drew'in yapmış olduğu üretimler genellikle kendi içinde ritmik bir biçimde hacimlenen, duvar ile ilişkisini korumaya devam eden, rölyeflerdir. Ancak bu üretimler teknik açıdan rölyef olarak yapılmış olsalar da, çoğu zaman üç boyuta ulaşarak, daha çok heykelin karasularına yaklaşmaktadır. Üretimin duvar yüzeyi ile kurduğu bu ilişki daha çok üretimin resme yaklaşmasını sağlarken zeminle kurduğu ilişki ise heykelin sınırlarına girer. Drew'in nesneleri arasında kimi zaman gözden düşmüş tüketim nesneleri yer alırken kimi zamanda bu nesnelerin el değmemiş hallerini kullanmayı tercih eder.

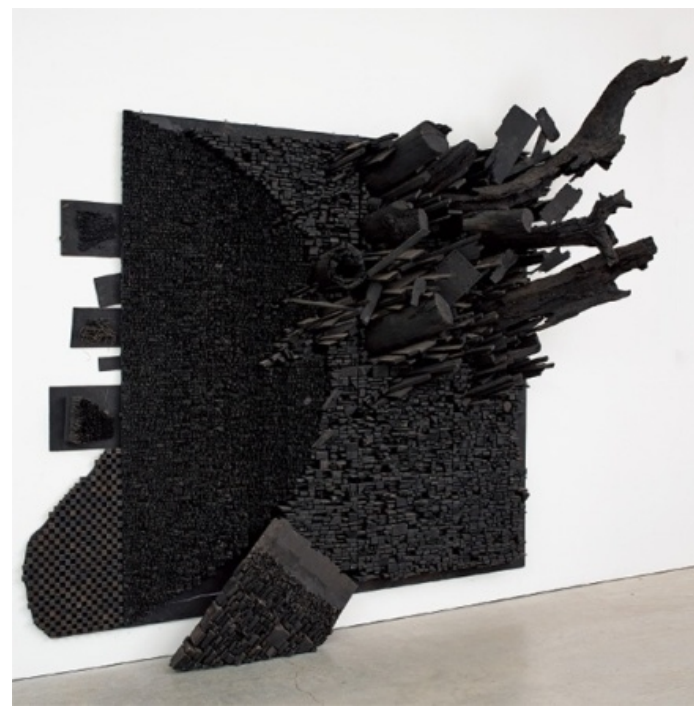

Görsel 5. Leonardo Drew, Numara 8, 1988, $108 \times 120 \times 4$ inç, hayvan leşleri, hayvan derileri, tüyler, boya, kâğıt, ip ve tahta

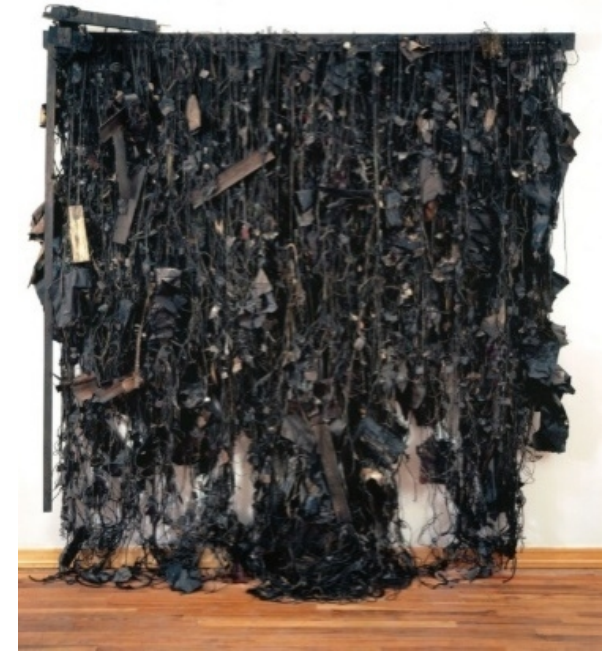

Görsel 6. Leonardo Drew, Numara 185, 2016, x 121x134 x 30 inç, ahşap, boya, pastel ve vidalar

McEvilley ise Drew'in üretimlerinden olan sayı 1, 2, 15, 8'de olduğu gibi birçok üretiminde duvar yüzeyine sabitlenen dikdörtgenimsi yapının tuval yüzeyini ima ettiğini ancak izleyicinin bulunduğu alana heykelsel olarak nüfus ettiğini söyler (McEvilley, 1996, s. 327-328). Sanatçının kendisi ise çalışmalarını resimden gelişen heykeller olarak yorumlarken, iki boyutlu kompozisyonu anlayan ancak tamamen üç boyutlu gerçekleşen heykeller olduğunun altını çizer (Allen, 2017).

Nevelson ve Drew'in aksine yüzeye daha yakın, alçak rölyef tarzında çalışan bir başka sanatçı ise Mark Bradford'dur. Sol Lewitt'in duvar yüzeyini boydan boya kaplayan çizimlerine benzer şekilde, duvar yüzeyini boydan boya, üst üste kolaj tekniği ile yığarak, kaplayarak çoklu kâğıt katmanları elde eder. Ardından Bradford'un yüzeye kazıyarak, keserek ve son olarak harmanlayarak müdahale ettiği görülür. Daha sonra sanatçı tarafından manipüle edilen, soyulan yüzey deformasyonlu hali ile sergilenir.

Sanatçının her biri $4 \mathrm{~m}$ yüksekliğinde, yaklaşık 50m uzunluğunda 8 panelden oluşan Pickett'in Ücreti adlı çalışması, Konfederasyon generali George E. Pickett'in Sendika kuvvetlerine karşı başarısız olduğu iç savaşta, en önemli anı gösteren Paul Dominique Philippoteaux' nun 19. yüzyıl Gettysburg Cyclorama'sına dayanır. Bradford'un rölyef konstrüksüyonunu Gettysburg Cyclorama'sına yaslaması gerçek anlamda Amerikan tarihini ve telafisi olmayan kayıplara ilişkin, bir tarih eleştirisi niteliği taşımaktadır (Wofford, 2018, s. 2). 


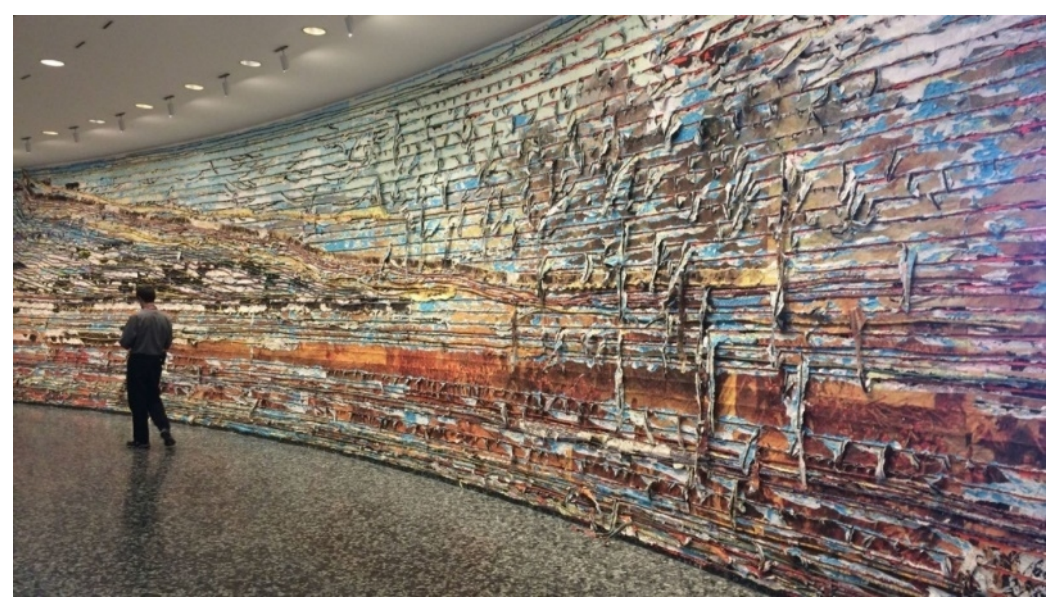

Görsel 7. Mark Bradford. Pickett'in Ücreti, 2017-2018

Bradford'unkolaj tekniğini kullanarak elde etmiş olduğu soyutlamalar, yüzeyin altındaki yatağa yerleştirilen ipin, daha sonra çekilerek yırtıklara, derin girinti ve çıkıntılara dönüşür. Sanatçı tarafından deforme edilen yüzeyde elde edilen renk konfigürasyonu resimsi imalar taşırken, yüzeyde yakalanan kütle ve hacim, alçak rölyefi destekler niteliktedir.

Hildebrand rölyefi öğelerine ayırırken "İki boyutlu düzlemde üç boyutlu imgenin derinliğine ilişkin birleşik bir yargıda uyandırdığı bölünmez etkiden" bahseder (Hildebrand, 2016, s. 67). Bu derinlik, söz konusu nesnenin düzlemde algılanabilir bir resmini verirken aynı zamanda kavranabilir hacmi içinde bir yargıda bulunmamızı sağlar. Nitekim rölyef heykel ve resim disiplinlerinin sahip olduğu özellikleri teknik olarak bir araya getiren bir yapılar bütünüdür. Bu sayede rölyefi yanılsama düzleminde illüzyonistlik bir biçimde algılarız. Tıpkı Natalie Charkow Hollander'ın yapmış olduğu rölyeflerdeki gibi. Hollander 'Piero Hakkında' ve '12 Mitolojik Görünüm' adlı çalışmalarında, mekân içindeki ilişkileri ön ve arka planlar halinde resimsi öğeler (perspektif) üzerinden irdelerken, figürler sert biçimde bırakılır. Rölyef düzleminin dışına taşmak yerine kütlenin içine doğru oyularak yükselmeye devam etmesi, içeride gölgenin oluşmasına, bu sebep de figürlerin ve mekânın vurgulandığına neden olduğu görülmektedir.

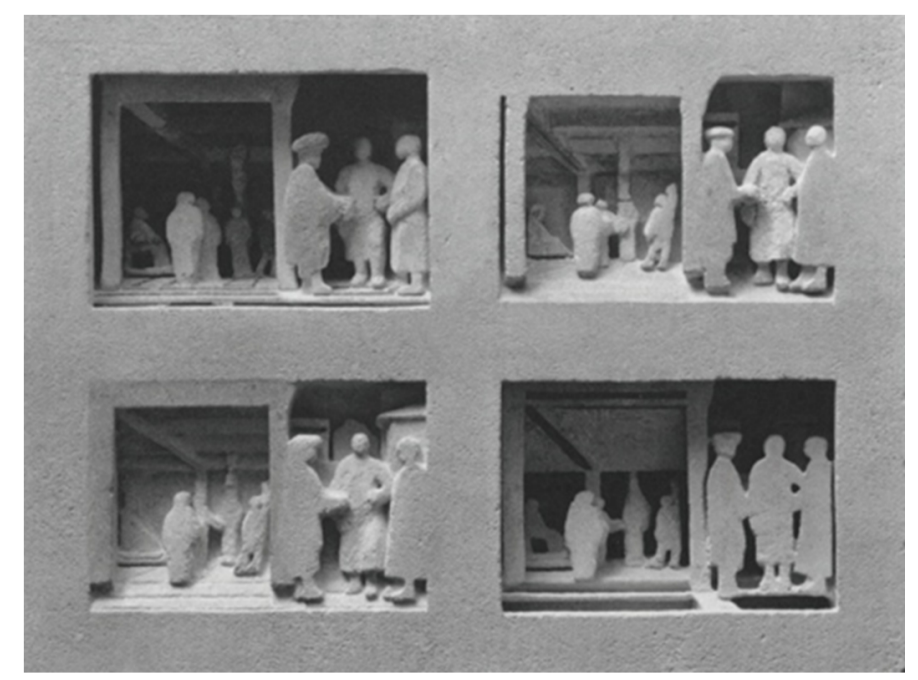

Görsel 8. Natalie Charkow Hollander, Regarding Piero/Piero Hakkında, 1999, kireç taşı, $35.6 \times 45.7 \mathrm{~cm}$

Wang ise Hollander'ın üretimlerini şu şekilde analiz eder:

Hollander rölyefi yeniden icat eder, kadim piktoryal mekân fikrini beklenmedik ve tamamen modern yapılara tercüme ederken aynı zamanda temsille kompleks bir diyaloga girer ve onu karşısına alır. Geleneksel rölyefte olduğu gibi mekânda üç boyutlu formlar inşaa etmek için düzlemlerinden kütleler inşaa etmek yerine, Hollander taş bloklarına bizim dış dünyamızla onun heykellerinin iç dünyası arasinda amansız bir ayrım gibi yaklaşır. Ortaya çıkan rölyefler seyirciden uzaklaşır, ona vücut veren taşın materyal gerçekliğinden kaçar gibi taş bloğun oyulmuş mekânının içinin derinliklerine doğru girer. Taş bloğun net bir şekilde tanımlanmış sınırlarının ötesine işleyen kapalı mekânlarını görür gibiyizdir (Wang, 2018, s. 176-177). 
Hollander üretimlerini yaparken, merkeze resmin yanılsamalı mekânını alırken aynı zamanda heykelsi özellikler ile harmanlar. Zaten rölyef resmin yanılsamalı görsel mekânı ile heykelin gerçek mekânı arasındaki derinlik havzasında yer alabilmesi en önemli özelliğidir (Atıl, 2015, s. 3). Hollander rölyefin bu özelliğini merkeze alarak üretim yapar. Bu açıdan görme eylemi, resimsi ve heykelsi özellikleri aynı düzlemde algılayabilmeyi olanaklı kılar. Hollander bu sayede ayrıntılandırma ve kaba bırakma gibi zıtlık içeren güçlü eylemlerle, rölyefte muazzam bir etki elde eder.

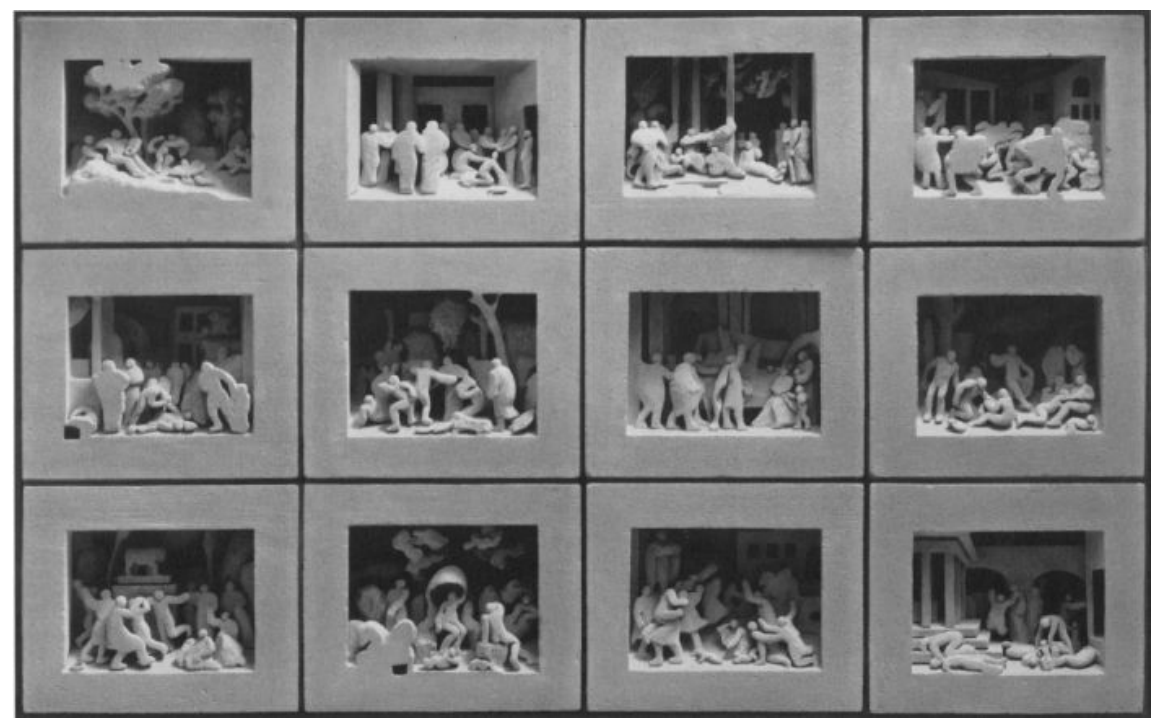

Görsel 9. Natalie Charkow Hollander, 12 Mitolojik Görünüm, 1999, 30 x 48 x 5 cm, kireçtaş1

Hollander'ın aksine Tülay Özkul, rölyef konusuna basit koordinatlar üzerinden yaklaşır. Bu koordinatlar tam olarak, resmin mekânı ile heykelin hacimsel/kütlesel varlığı ile ilişki içerisinde yer alır. Özkul, Atölye İşleri serisinde yer alan üretimleri ile bir heykeltıraşın, bir marangozun, bir mimarın, bir inşaat işçisinin ya da bir endüstriyel tasarımıının çalışma esnasında kullanmış olduğu ortak nesneleri ele alır/yorumlamalarda bulunur.

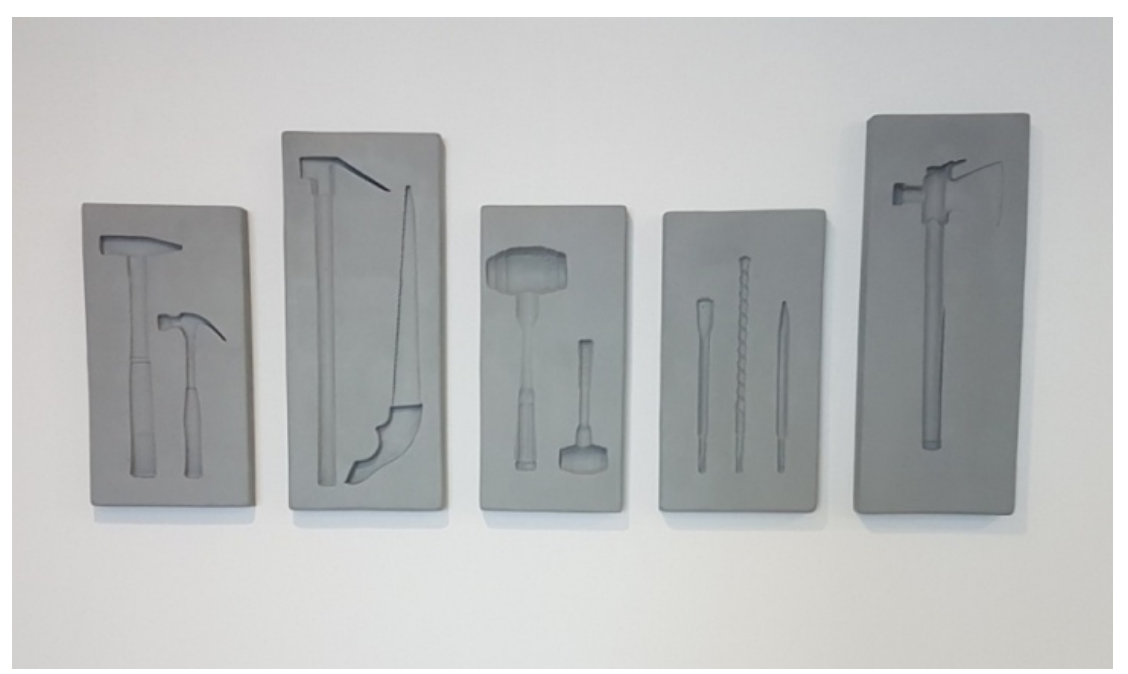

Görsel 10.Tülay Özkul, Atölye İşleri, 2019, Vurma-Kırma-Yontma serisi, No. 1 Çekiç, 43x23x4 cm; No. 2 Keser/Bıçk1, 56x22x4 cm; No. 3 Tokmak, 45x22x4 cm; No. 4 Mucarta, 44x23x4 cm; No. 5 Nacak, 56x22x4 cm

$\mathrm{Bu}$ nesneler insanoğlunun kadim antik çağlardan günümüze kadar kullandığı basit el aletlerinin atalarının çağdaş versiyonları konumundadır. Ancak bu aletler endüstrileşen insanoğlu ve onun üretimleri bağlamında özellikle kurgulamaya veya inşa etmeye başladığından beri birçok disiplinin ortak alanında yer almaktadır. İlk olarak ham maddesi taş, bakır vb. gibi madenler olan el aletleri, nesilden nesile aktarılarak, günümüze dek ulaşmışlardır/ulaşacaktır. Bugün, el aletlerinin görüntüleri, teknolojik ilerleme sayesinde değişmiş olsa bile ilk icat edildikleri dönemlerdeki aynı niyetler ile kullanılmaya devam etmektedir. Bu nesneler her dönemde insanoğlunun kendisi ve çevresi için kurduğu fiili mekânın/alanın yanı sıra bir anlamda onun hayallerinin bir parçasını oluşturabilmek için ve biçim verme eyleminin tam ortasında durmasının yanı sıra özellikle yaratıcı gücün hayat bulması açısından da günlük kullanım nesneleri arasında yerlerini almaya devam etmektedir. 


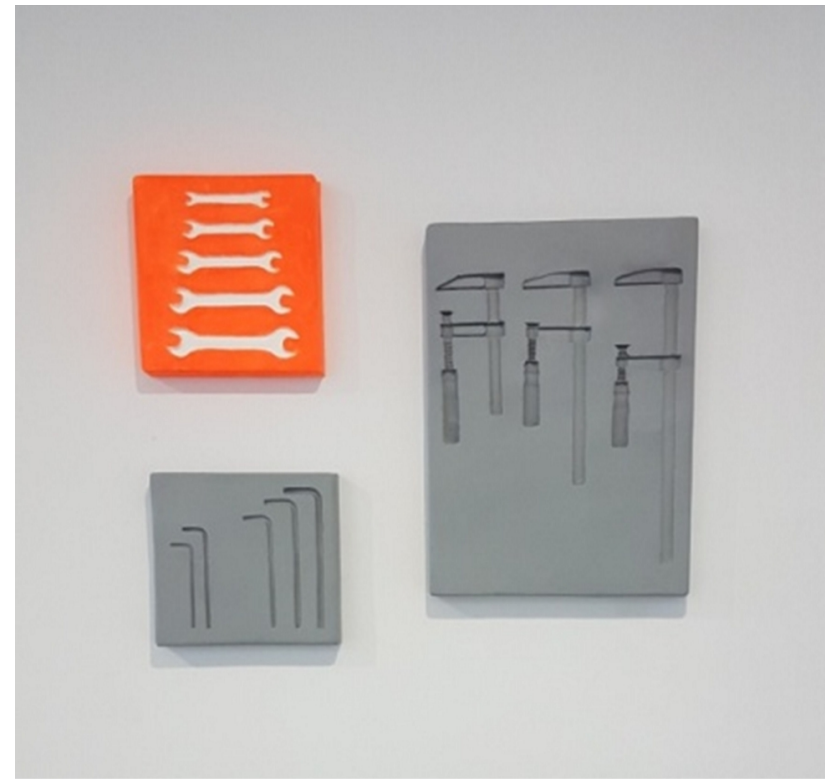

Görsel 11. Tülay Özkul, 2019, Kipleştirme Serisi No. 1 Somun Anahtarı, 33x22x4 cm; No. 2 Alyan, 23x23x4 cm; No. 3 İşkence, $45 \times 33 \times 4$ cm

Aynı zamanda bir atölyede ya da bir alet dolabında olması gereken bu nesneler, Özkul'un mutfak lavabosunun altındaki dolapta yer alırlar. Bir kadın/ bir eş/bir anne/ bir kardeş/bir heykeltıraş/bir akademisyen olan Özkul, Atölye İşleri'nde yer alan nesneleri tüm üretimlerini yapmış olduğu kendi mutfağında el altında tutar, barındırır. Mutfak, genel anlamda birçok kadın tarafından evin merkez konumuna yerleştirilen, rol ve sorumluluklarının büyük kısmını oluşturan bir yer anlamı da taşımaktadır. Bu sebeple; bir anlamda mutfak kavramı nesnel boyutta da kadının üretkenliğini/yaratıcılığını gösterdiği mekân anlamına gelirken; aynı zamanda aile bireylerinin beslenme döngüsünün gerçekleştirildiği/gerçekleştiği yerdir. Bu çerçeveden bakıldığında mutfağın, kadınla ilişkilendirilen, dişi bir yer olma özelliği taşıdığı söylenebilir. Atölye İşleri’nde ise, toplum tarafından kadına verilen rollerin içinde yer alan pişirme, doyurma, temizleme, yıkama, derleme, toplama gibi temel ev işleri döngüsünde yer alan eylemlerin yerine Özkul tarafından çalışmalarında sorgulanan kırma, yontma, sıvama, kesme, koparma, hizalama, vurma gibi eylemler konulur. Bu anlamda aynı temel ev işlerinin yanı sıra sanatsal üretimleri de kapsayan üretimler genelde aynı mekânda (mutfakta) hatta özelde aynı tezgâhta gerçekleşen farklı üretimler bağlamında bir araya gelir. Özkul'un üretimlerinde mutfak işleri ile atölye işıleri birbirleri içinde erir/eritilir. Belirli ölçeklerde oluşturulan düzlemler içinde şekillendirilen el aletleri arasında işkence, İngiliz anahtarı, şakül, nacak, testere, tokmak, çekiç, keser, mucarta, mala, firça, yan keski, pense, karga burun, spatula, gönye vb. aletler yer almaktadır. Bu aletler kendi içlerinde belli başlıklar altında gruplandırılarak, belli bir izleme rotası oluşturulur. Bu rota inşa etme eylemi üzerine kurulu olduğundan kendi yaratılış amaçları doğrultusunda koordinatlara yerleştirilir.

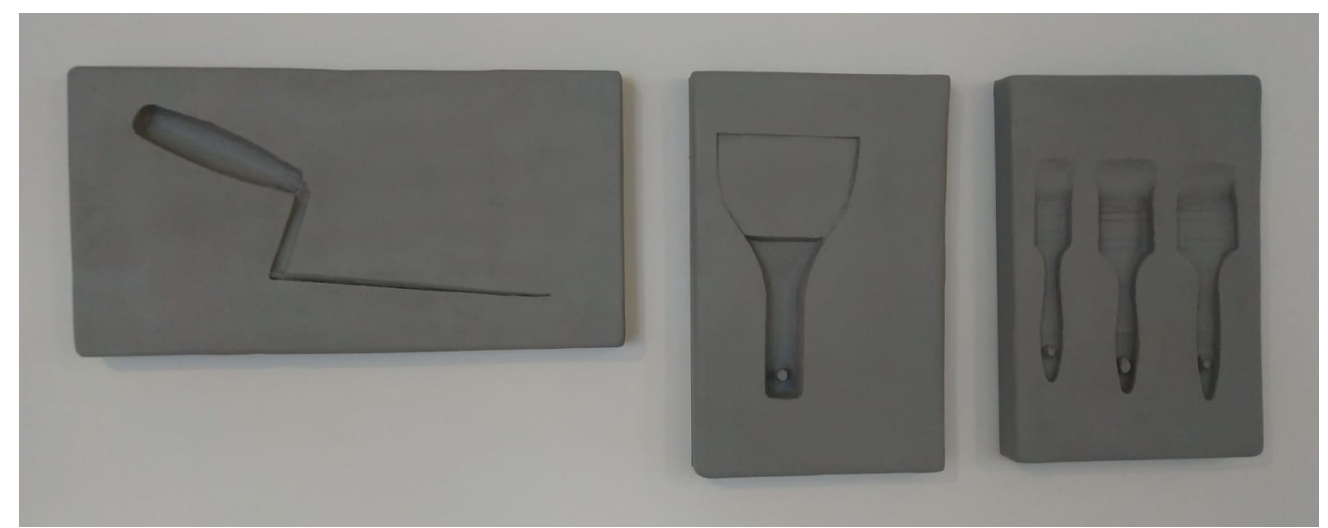

Görsel 12. Tülay Özkul, 2019, Sıvama Boyama Serisi, No. 1 Mala, 43x22x4 cm; No. 2 Spatula, 34x21x4 cm; No. 3 Frrça, $33 \times 23 \times 4$ cm

Örneğin halk dilinde 'kipleştirme' olarak anılan sağlamlaştırma, sıkıştırma, sertleştirme, birleştirme ve bitiştirme anlamlarını taşımaktadır (Kipleştirmek, 2019). Bu sebeple Kipleştirme Serisinde yer alan İşkence, Alyan ve Somun anahtarı, işlevleri doğrultusunda yani sıkılaştırma, sağlamlaştırma, birleştirme işlemlerini sağladıkları için aynı grupta yer almaktadır. 
Atölye İşleri'nde girinti ve çıkıntıların, yükselişlerin ya da izleyicinin bulunduğu alana nüfus etmesinin aksine duvar yüzeyinde sadece belli derinlikte oyuntular şeklinde, sade bir biçimde bırakılmıştır. Bu girintiler nesnenin orada olduğuna işaret edecek şekilde negatif bir biçimlendirme doğrultusunda şekillendirilerek, nesnelerin kontur hatları boyunca Mısır Rölyefleri'nde olduğu gibi gölgelendirmeler oluşturacak şekilde, derinlik vurgusu yakalanmıştır.

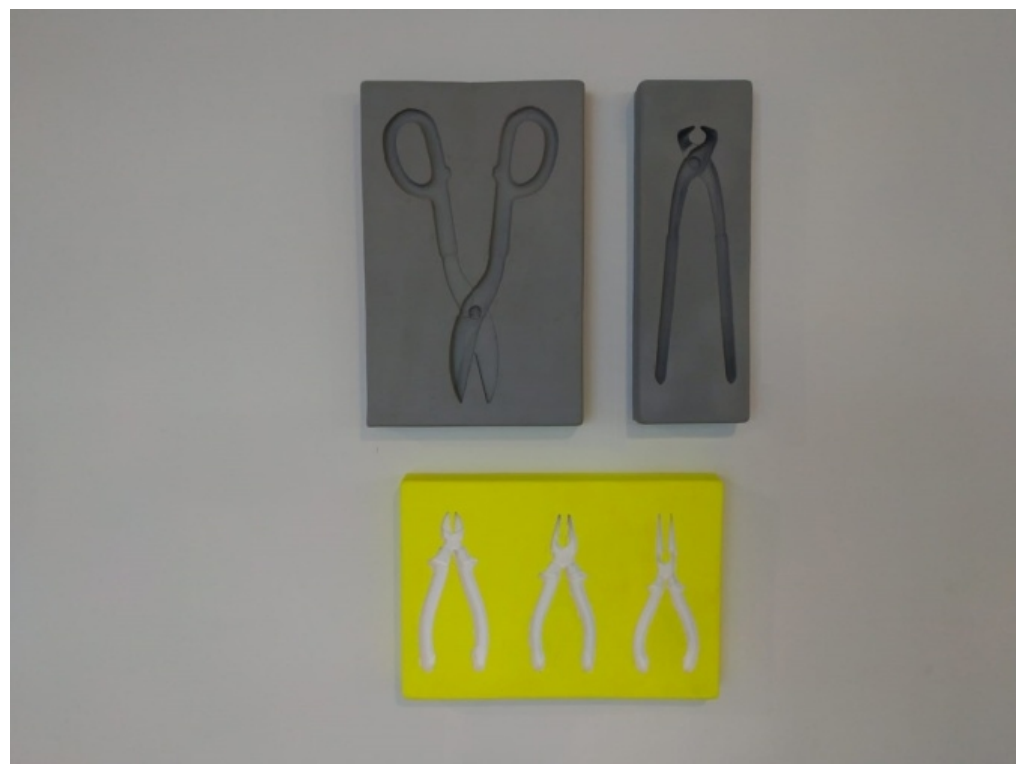

Görsel 13. Tülay Özkul, 2019, Koparma Serisi, No. 1 Tel Makası, 36x22x4 cm; No. 2 Yankeski/Pense/Kargaburun, 33x23x4cm; No. 3 Kerpeten, $34 \times 11 \times 4 \mathrm{~cm}$

Duvar yüzeyinde yükselen rölyef desteği, düzleminde oluşturulan belli seviyelerdeki derinlik ile yüzeyde oluşturulan yanılsamayı desteklerken resim düzlemine gönderme yapar. Aynı zamanda Özkul, Atölye İşleri’nde renk öğesini aktif biçimde kullanarak seriler arasındaki görsel geçişin rahatlamasını sağlar. Bu renkler arasında, zıtlık oluşturacak şekilde fosforlu canlı renk tonları ile daha nötr bir renk olan gri kullanılmıştır. Gri rengin betonu/evi çağrıştırması amaçlanırken, fosforlu renkler ile dişil söylem pekiştirilmiştir.

\section{Sonuç yerine}

Sonuç olarak Bradford, Nevelson, Drew, Hollander ve Özkul'un ele aldıkları kavramlar ve malzemeler farklı olsa da resim ile heykelin özelliklerinin kesiştikleri alan olarak rölyef tekniğinde buluştukları ve aynı payda da yer aldıkları görülür. Geleneksel rölyef anlayışına kısmen yaslanan ancak gerçek anlamda bu anlayışa yeni önermelerde bulunan bu sanatçılar, resimsel ve heykelsel özellikleri, yapmış oldukları üretimlerin temellerine yerleştirirler. Rölyef tekniğinin temel prensiplerinde yer alan resimsi ve heykelsi işaretler bu sanatçılar tarafından zaman zaman ima etmenin ötesine götürülerek rölyefin sınırları zorlanır. Bu anlamda konu kapsamında ele alınan sanatçı üretimlerinin geleneksel rölyefi tamamen dışlamadığı gibi tam anlamıyla içine aldığı da söylenemez. Genel bir değerlendirme yapıldığında çağdaş sanatta rölyefin bir dönüşüm geçirdiğii, onun bu dönüşümünde bağlı olduğu resim ve heykel disiplinlerinin sınırlarının yeniden tanımlandığı ortaya çıkmaktadır.

\section{Kaynakça}

Absolon, K. (1949). The diluvial anthropomorpfic statues and drawings, especially the so-called Venuz Statuettes, discovered in Moracia: a comparative study. Arbitus Asiae, 12(3), 201-202.

Allen, J. İ. (2017). Making chaos legible: a conversation with Leonardo Drew. A Publication of The International Sculpture Center, 36(9). Erişim adresi: https://www.sculpture.org/documents/scmag17/nov_17/ fullfeature.shtml

Atıl, A. (2015). Rölyef heykel. Yedi: Sanat, Tasarım ve Bilim Dergisi, 14, 1-10.

Bostancı, N. (2014). Paleolitik çăg kadınları. A. Engin, B. Helving ve B. Uysal (Ed.), Armizzi-Engin Özgen’e Armağan (s. 191-204) içinde. Ankara: Atatürk Kültür Merkezi Başkanlığı Yayınları.

Gombrich, E. H. (2015). Sanatın Öyküsü. (Ö. Erduran ve E. Erduran, Çev.). İstanbul: Remzi Kitapevi.

Hildebrand, A. (2016). Resimde ve heykelde biçim sorunu. (H. Anay, Çev.). İstanbul: Janus Yayıncılık.

Hodder, I. (2006). Çatalhöyük, leoparın öyküsü, Türkiye’nin antik kasabasının gizemleri günışı̆̆ına çıkıyor. (D. Şendil, Çev.). İstanbul: Yapı Kredi Yayınları. 
Kipleştirmek. (2019). Erişim adresi: https://kelimeler.gen.tr/kiplestirmek-nedir-ne-demek-193937

McEvilley, T. (1999). Sculpture in the age of doubt. New York: Allworth Press.

MoMA. (2019). Erişim adresi: https://www.moma.org/collection/works/81006

Özkul, T. (2019). Çağdaş sanatta kütle yüzey ilişkisi (Sanatta Yeterlik Tezi). Ankara Hacı Bayram Veli Üniversitesi Lisansüstü Eğitim Enstitüsü, Ankara. YÖK tez veri tabanından erişildi (Tez No. 549029).

Pera Müzesi. (2017). Sanatta Venüs. Erişim adresi: https://blog.peramuzesi.org.tr/sergiler/sanatta-venus/

Rogers, L. R. (1969). Heykel. Londra: Oxford Üniversitesi Yayınları.

Rona, Z. (2008). Eczacıbaşı sanat ansiklopedisi. (2. Cilt). İstanbul: Yem Yayınları.

Rölyef. (2019). Etimoloji Türkçe. Erişim adresi: https://www.etimolojiturkce.com/kelime/r\%C3\%B6lyef

Sadıkoğlu, P. (2007). Antik Mısır sanatı ve tarihsel akış̧tan günümüze etkiler. İstanbul: Boyut Matbaacılık.

Sunan, Atalay, M. (2012). Keramik rölyef sanatı ve uygulama. 6. Uluslararası Eskişehir Pişmiş Toprak Sempozyumunda sunulan poster, Eskişehir. Erişim adresi: https://www.academia.edu/35647109/ keram $\% \mathrm{c} 4 \% \mathrm{~b} 0 \mathrm{k} \_\mathrm{r} \% \mathrm{c} 3 \% 96 \mathrm{yef}$ _sanat__ve_uygulama_keramik_relief_art_and_application

TDK. (2019). Rölyef. Erişim adresi: https://tdk.gov.tr.

Tekin, A. (2019). Paleolitik çağ'ın kadın figürinleri. Gorgon E-Dergisi, 6, 51-66.

Tıgın, Y. (2014). Sanat-hayat bağlamında nesnelerin yeniden okunması (Yüksek Lisans Tezi). Hacettepe Üniversitesi Güzel Sanatlar Enstitüsü, Ankara. YÖK tez veri tabanından erişildi (Tez No. 367900).

Turani, A. (2017). Dünya sanat tarihi. (20. Bask1). İstanbul: Remzi Kitapevi.

Waldman, D. ( 1992). Collage, assemblage and the found object. New York: Harry N. Abrams.

Wang, Y. (2018). The relief problem: some notes from an art historian. Ars Orientalis, 48, 166-79.

Wofford, T. (2018). Mark Bradford: Pickett's charge. Journal of The Association of Historians of American Art Panorama, 4.2. Erişim adresi: https://editions.lib.umn.edu/panorama/article/mark-bradford-pickettscharge/

Wölfflin, H. (2015). Sanat Tarihinin Temel Kavramları. (A. Cemal, Çev.). İstanbul: Hayalperest Yayınevi.

Yılmaz, B. (2015). Atık nesneden sanat yapıtına malzemenin dönüşümü. Süleyman Demirel Üniversitesi Güzel Sanatlar Fakültesi Hakemli Dergisi ART-E, 15, 185-197.

Yılmaz, M. (2006). Heykel sanatı. Ankara: İmge Kitapevi.

\section{Görsel Kaynakçası}

Görsel 1. Lassuel Kadını, M.Ö. 25000. Erişim adresi: http://arkeofili.com/paleolitik-donemden-en-etkileyici-10venus/

Görsel 2. Michelangelo, Musa, 1513-1515. Erişim adresi: http://picdeer.com/tag/musan\%C4\%B1nh\%C3\% $\mathrm{BCkm} \% \mathrm{C} 3 \% \mathrm{BC}$

Görsel 3. Mısır'daki Chnum Tapınağı'nda taş kabartma. Erişim adresi: https://www.google.com/search?q=M\% $\mathrm{C} 4 \% \mathrm{~B} 1 \mathrm{~s} \% \mathrm{C} 4 \% \mathrm{~B} 1 \mathrm{r} \% 27$ daki+Chnum+Tap $\% \mathrm{C} 4 \% \mathrm{~B} 1 \mathrm{na} \% \mathrm{C} 4 \% 9 \mathrm{~F} \% \mathrm{C} 4 \% \mathrm{~B} 1 \% 27 \mathrm{nda}+\mathrm{ta} \% \mathrm{C} 5 \% 9 \mathrm{~F}+\mathrm{kabartm}$ $\mathrm{a} \& \mathrm{tbm}=$ isch\&source $=$ univ\&sa $=$ X\&ved $=2 \mathrm{ahUKEwi} 4 \mathrm{kuKm} 7 \mathrm{jj}$ AhWLuIsKHaCtDzYQsAR6BAgJEAE\&bi $\mathrm{w}=1920 \& \mathrm{bih}=937 \#$ imgrc $=$ HnU5MEWC7zyM-M:

Görsel 4. Louise Nevelson, Gökyüzü Katedrali, 1958, $343.9 \times 305.4 \times 45.7$ cm, boyalı ahşap. Erişim adresi: https://americanart.si.edu/artwork/sky-cathedral-34071.

Görsel 5. Leonardo Drew, Numara 8, 1988, $108 \times 120 \times 4$ inç, hayvan leşleri, hayvan derileri, tüyler, boya, kâğıt, ip ve tahta. Erişim adresi: https://art21.org/gallery/leonardo-drew-artwork-survey-1980s/

Görsel 6. Leonardo Drew, Numara 185, 2016, x 121x134 x 30 inç, ahșap, boya, pastel ve vidalar. Erișim adresi: https://www.google.com/search?q=Leonardo+Drew, + Numara $+185 \&$ source $=1$ mms\&tbm $=$ isch\&sa $=$ X\&ved $=0$ ahUKEwjCi7Lu_bjjAhVJa8AKHWDoC28Q_AUIECgB\&biw=1920\&bih=937\#imgrc=hAabmcCPpXviM

Görsel 7. Mark Bradford, Pickett'in Ücreti, 2017-2018. Erişim adresi: https://www.latimes.com/entertainment/ arts/miranda/la-et-cam-mark-bradford-hauser-wirth-20180219-htmlstory.html. 
Görsel 8. Natalie Charkow Hollander, Regarding Piero/Piero Hakkında, 1999, Kireç taşı, $35.6 \times 45.7 \mathrm{~cm}$. Erişim adresi: https:/quod.lib.umich.edu/a/ars/13441566.0048.006/--relief-problem-some-notes-from-an-arthistorian?rgn=main; view=fulltext.

Görsel 9. Natalie Charkow Hollander, 12 Mitolojik Görünüm, 1999, 30 x 48 x 5, Kireçtaş1. Erişim adresi: https://www.pinterest.es/ pin/368450813241784679

Görsel 10. Tülay Özkul, Atölye işleri, 2019, Vurma-Kırma-Yontma Serisi, No. 1 Çekiç, 43x23x4 cm, No. 2 Keser/Bıçkı, 56x22x4 cm, No. 3 Tokmak, 45x22x4 cm, No. 4 Mucarta, 44x23x4 cm, No. 5 Nacak,56x22x4 $\mathrm{cm}$. Tülay Özkul arşivinden alınmıştır.

Görsel 11. Tülay Özkul, 2019, Kipleştirme Serisi, No. 1 Somun Anahtarı, 33×22x4 cm, No. 2 Alyan, 23×23×4 cm, No. 3 İşkence, 45x33x4 cm. Tülay Özkul arşivinden alınmıştır.

Görsel 12. Tülay Özkul, 2019, Sıvama Boyama Serisi, No. 1 Mala, 43x22x4 cm, No. 2 Spatula, 34x21x4 cm, No. 3 Fırça, 33x23x4 cm. Tülay Özkul arşivinden alınmıştır.

Görsel 13. Tülay Özkul, 2019, Koparma Serisi, No. 1 Tel makası, 36x22x4 cm, No. 2 Yan keski/Pense/Karga burun, 33x23x4 cm, No. 3 Kerpeten, 34x11x4 cm. Tülay Özkul arşivinden alınmıştır. 